\title{
Aspects of Cameroon Francophone English (CamFE) Phonology
}

\author{
Gilbert Tagne Safotso \\ Department of English Language and Literature of English Expression, Higher Teacher Training College, University of \\ Maroua, P.O. BOX 282 Dschang /55 Maroua, Cameroon \\ Email: gilbertsafotso@gmail.com
}

\begin{abstract}
This paper analyses some aspects of English pronunciation of French-Speaking Cameroonians termed Cameroon Francophone English (CamFE) to show that this variety of New Englishes has stable features. The data come from the oral reading of some selected words and sentences (see the appendix) by 50 French-speaking Cameroonian subjects of different levels of education, radio broadcasts ( especially Morning Safari $^{1}$ ), TV debates, political speeches, casual conversations and seminar sessions. The focus is on the production of plural forms $/ 3^{\text {rd }}$ person singular markers 's, -ses, -ies, -oes', the simple past tense and past participle morpheme '-ed', consonant clusters, word stress, and the frenchified reading of some English words. The analysis is done from the contrastive analysis, interlanguage and language transfer perspective. Findings show that although the subjects have different levels of education and speak varied mother tongues, they produce the areas of English phonology studied in the same way. The study concludes that, although some features of this variety of New Englishes are common to all Cameroonian learners/speakers of English as well as to many other world Englishes, there are some hallmarks proper to CamFE, and draws the pedagogical implications.
\end{abstract}

Index Terms - CamFE, simple past tense, plural forms, word stress, consonant clusters

\section{INTRODUCTION}

In multilingual settings, English pronunciation is generally an issue of great concern. The situation is more complex in Cameroon because research shows that throughout the country there are two English accents which differ from each other and from other New Englishes/ RP. The first variety is that of the English-speaking Cameroonians termed Cameroon English (CamE) (Simo Bobda 1986, 1994, 2010; Simo Bobda and Chumbow 1999; Kouega 1991, 1999, 2000; Ebot 1999). The second variety is that of the French-speaking Cameroonians (Tagne Safotso 2001, 2006; Kouega 2008). Kouega calls this variety of English Francophone English (FancoE). But this appellation seems inappropriate because it may refer to any non-native variety of English spoken by francophones anywhere in the world. The appellation CamFE (Cameroon Francophone English) would thus be more appropriate because closely related to the parent CamE . It is the variety of English spoken by the vast majority of Cameroonians. According to the 2010 census, $16,217,119(83.56 \%)$ Cameroonians over a population of 19,406,100 inhabitants are francophones. Although research on the phonology of this second variety is still embryonic, it shows that it has quite a number of stable features different from those of CamE/ RP.

This paper (1) examines five aspects of CamFE phonololgy: (1) the plural forms $/ 3^{\text {rd }}$ person singular markers ${ }^{\text {, }}-\mathrm{s}$, ies,- es,- oes', (2) the simple past tense and past participle morpheme '-ed', (3) consonant clusters, (4) word stress (5) and the frenchified pronunciation of some English words. The study ends with some pedagogical implications.

\section{METHOD}

The data come from several sources: the oral reading of some selected words and sentences (see the appendix) by 50 French-speaking Cameroonian subjects of different levels of education, radio broadcasts (especially Morning Safari) ,TV debates, political speeches,casual conversations, and seminar sessions. The subjects who did the oral reading comprised 10 Terminale $^{2}$ learners, 30 undergraduate students and 10 postgraduate French-speaking bilingual student teachers. This aimed to check if the level of education variable has an impact on the subjects' production. The data was analysed from the Interlanguage, Contrastive Analysis and Language Transfer perspective with RP and CamE being the contrastive models.

\section{The Linguistic BACKGROUND OF FrENCH-SPEAKING CAMEROONIAN LEARNERS OF ENGLiSH}

In Cameroon, it is commonly assumed that each citizen has a mother tongue (or home language) besides the two official languages (French and English). Although this assumption is becoming questionable in urban centres (Djimeli 1997; Haman Bello 1997; Bitja'a Koddy 2001; Simo Bobda 2006; Njika 2006) where some Cameroonian children exclusively speak French, English or Pidgin English, to a large extent, the great majority of Cameroonians have a mother tongue. In many rural communities (if not all) and in some urban centres many people use only their mother 
tongue as means of communication. Some children can even speak up to two home languages besides French or English. This mostly happens with children from interethnic marriages (Tenjoh-Okwen, 1985, pp.18-20). Mba (2009) points out that the vast majority of Cameroonians are multilingual though in most cases they can only write one or two of the languages they speak (p.553).

In the Francophone subsystem of education (Cameroon has two subsystems of education: the Francophone subsystem and the Anglophone subsystem), at the level of primary school, the medium of instruction is French. English is taught only as a school subject (English as a Foreign Language). This is effective now in all classes of primary school throughout Cameroon since the introduction of the English paper at the CEP, (Certificat d'Etudes Primaires) and the French paper at the First School Leaving Certificate (Order $n^{\circ} 66 / \mathrm{C} / 13$ of $16^{\text {th }}$ February, 2001). In northern Cameroon and in some major towns of the southern part of the country, some primary school learners first learn Arabic in mosques before attending formal school. These particular learners sometimes cause serious problems to teachers as they write from right to left.

In the third year of secondary school, Francophone learners have to learn another language besides French and English. The choice is between German, Spanish and Arabic3. Students who study in the Anglophone subsystem of education do not do this. The only languages taught/learned in that subsystem are English and French.

At the university level, Francophone learners register to study various subjects such as mathematics, physics, French language, English language, Spanish or German. Some register for bilingual studies (combined English-French degree), and others for trilingual studies, i.e. combined French-English-Italian, French-English-German or French-EnglishSpanish degree. So far in Cameroon, this degree can be obtained only from the University of Dschang. Except students who study for a bilingual or a trilingual degree, all the rest of Francophone learners are compelled to study English within the framework of Bilingual Training. They do it during the first three years of their university studies (Biloa, 1999, p.53; Echu, 1999, p.1; Tagne Safotso 2011). Hence, when one meets an educated Francophone Cameroonian, his linguistic background may be quite complex. Apart from his mother tongue, he has formally learned at least three other languages. Combined with his personal variables (Gardner and MacIntyre 1992, 1993), these languages may be what makes the peculiarity of the English pronunciation of French-Speaking Cameroonians.

\section{RESULTS}

A careful analysis of the sample speech produced by learners from Terminale to post graduate level showed that their production was not different from that heard on the radio/ TV, in political speeches, casual conversations, and seminars. As a matter of fact, The vast majority of French-speaking Cameroonians who speak on The radio/ TV, deliver political speeches, take part in debates or seminars in English have at least a graduate level. The findings in the five areas investigated are presented below.

\section{A. The Production of the Plural Forms/ $3^{\text {rd }}$ Person Singular Markers}

French- speaking Cameroon users/ learners generally silence the markers of the plural/ $3^{\text {rd }}$ person singular '-s, -es, ies, -oes ,-os', or occasionally articulate them /s/ as illustrated in table 1 below.

TABLE 1

\begin{tabular}{|c|c|c|c|}
\hline \\
\hline $\begin{array}{l}\text { Word } \\
\text { rings }\end{array}$ & $\begin{array}{l}\text { RP form } \\
\text { [rıyz] }\end{array}$ & $\begin{array}{l}\text { CamFE form } \\
\text { [rin/rins] }\end{array}$ & $\begin{array}{l}\text { CamE form } \\
\text { [rins] }\end{array}$ \\
\hline shop $\underline{\underline{s}}$ & [Jpps] & [〕əp] & [厅॰ps] \\
\hline shorts & [ $\left.\int \mathrm{o:ts}\right]$ & {$\left[\int \partial t\right]$} & {$\left[\int わ t s\right]$} \\
\hline runs & {$[\mathrm{r} \wedge \mathrm{nz}]$} & [ron] & [rons] \\
\hline writes & [raits] & [rait] & [raits] \\
\hline calabash $\underline{\underline{e s}}$ & {$\left[\mathrm{k} æ l ə b æ \int_{\mathrm{IZ}}\right]$} & [kalabaj] & [kalabafis] \\
\hline crashes & {$\left[\mathrm{kræ} \int_{\mathrm{Iz}}\right]$} & {$\left[\mathrm{kra} \int\right]$} & [kraSis] \\
\hline instances & [Instənsız] & [instãs] & [instansis] \\
\hline buses & [bısIz] & [bys/bysis] & [bosis] \\
\hline bellies & [belız] & [beli/belis] & [belis/belis] \\
\hline societies & [səsaitız] & [sosaiti] & [sosaitis] \\
\hline mangoes & [mæทgəu z] & [mango] & [mangos] \\
\hline negroes & [ni:gruəz] & [negro/negros] & [negros] \\
\hline potatoes & [pəteItəu z] & [poteto] & [potetos] \\
\hline photos & [fəutəuz] & [foto] & [fotos] \\
\hline
\end{tabular}

It can be remarked that the silencing of the markers of the plural/ $3^{\text {rd }}$ person singular is very characteristic of the English pronunciation of French-speaking Cameroonians (Tagne Safotso, 2001, pp. 22-35). When the subjects occasionally articulate them ,they pronounce them /s/ or /is/ irrespective of the vowel or the voiced nature of the consonants that precede the marker (this happens mostly with the postgraduate bilingual student teachers). The same observation can be made with CamE speakers. With CamFE speakers this problem may be due to French, because the plural markers are silent in that language, and because the singular noun is differentiated from the plural one by the 
article, e.g. la table [la tabl] (singular); les table $\underline{\text { s }}$ [le tabl] (bench; benches). French may also account for the difficulty in the $3^{\text {rd }}$ person singular because in that language the $3^{\text {rd }}$ person singular is not marked in the verbs of the $1^{\text {st }}$ group. Even when it is marked in the verbs of the $2^{\text {nd }}$ and $3^{\text {rd }}$ groups, it remains silent, e.g. il bénit, il mord [il beni, il mor] (he blesses/bites).

\section{B. The Production of the Simple Past Tense and Past Participle Morpheme'-ed'}

In CamFE, the '-ed' affix of the simple past tense and past participle of regular verbs is articulated in two ways. It is either silenced or pronounced /ct/ as shown below.

TABLE 2

\begin{tabular}{|c|c|c|c|}
\hline $\begin{array}{l}\text { Word } \\
\text { separated }\end{array}$ & $\begin{array}{l}\text { RP form } \\
\text { [seporeitId] }\end{array}$ & $\begin{array}{l}\text { CamFE form } \\
\text { [separet/separetst] }\end{array}$ & $\begin{array}{l}\text { CamE form } \\
\text { [separetzt] }\end{array}$ \\
\hline walked & [wpkt] & [wolk] & [wokt] \\
\hline planted & [pla:ntId] & [plan/plantet] & [plantet] \\
\hline ended & [Endid] & [end/sndet] & [endet] \\
\hline concluded & [kənklu:did] & [konklud] & [konkludet] \\
\hline allowed & [əlau d] & [alowe] & [alaut] \\
\hline traced & [treIst] & [tras] & [trest] \\
\hline asked & {$[\alpha: s k t]$} & [as/asket] & [ast] \\
\hline finished & {$\left[\mathrm{fInI} \int \mathrm{t}\right]$} & [finif] & [finift] \\
\hline returned & [rit3nd] & [riton] & [riten] \\
\hline damaged & [dæmıd3] & [damez/damef] & [dame3t] \\
\hline
\end{tabular}

The examples above show that French-speaking Cameroonians consistently silence the "-ed" affix of the simple past tense/past participle of regular verbs. When they attempt to pronounce it they articulated it /\&t/.This generally occurs with verbs that end in -ted/-ded as in CamE. The insertion of the epenthetic/\&/ and the devoicing of the final /d/ operates as in that variety of English (Simo Bobda, 1994, p.220). If the devoicing of the final /d/ can be attributed to the parent CamE, as it is the variety of English spoken by the vast majority of Cameroonian English teachers, the reason for the silencing of the affix is still to be elucidated. The production of consonant clusters is examined in the next section.

\section{The Production of Consonant Clusters}

The subjects generally reduce consonant cluster of two consonants (cc) to one and those of three consonants (ccc) to two or even one as illustrated in table 3 below.

TABLE 3

\begin{tabular}{|c|c|c|c|c|c|}
\hline \multicolumn{6}{|c|}{ CONSONANT CLUSTERS IN CAMFE, CAME AND RP } \\
\hline RP & Substitute cluster & Word & RP form & CamFE form & CamE form \\
\hline fj & $\rightarrow \mathrm{f}$ & furious & [fjuərəs] & [fyrios] & [furios] \\
\hline ld & $\rightarrow 1$ & told & [təuld] & [tol] & [tol] \\
\hline nt & $\rightarrow \mathrm{n}$ & went & [went] & [wen] & [went] \\
\hline $1 \mathrm{z}$ & $\rightarrow 1$ & girl $\underline{s}$ & [g3:lz] & [gel] & [gels] \\
\hline$\eta \mathrm{k}$ & $\rightarrow \mathrm{n}$ & think & {$[\theta \mathrm{Ink}]$} & [tsin] & [tink] \\
\hline ¡kl & $\rightarrow \mathrm{nl}$ & frankly & [fræykli] & [franli] & [franli] \\
\hline nts & $\rightarrow \mathrm{n}$ & parents & [peərənts] & [paren] & [perents] \\
\hline stj & $\rightarrow \mathrm{st}$ & students & [stju:dənts] & [styden] & [students] \\
\hline nld & $\rightarrow \mathrm{nl}$ & landlord & [lændlo:d] & [lanlo] & [lanlod] \\
\hline mpld & $\rightarrow \mathrm{mpl}$ & trampled & [træmpld] & [trampl] & [tramplt] \\
\hline
\end{tabular}

It can be observed that the subjects generally drop the last consonant of the clusters. This feature is characteristic of most non-native Englishes (Wong, 1981, p.272; Todd and Hancock, 1986, p. 96; Gbenga Fakuade, 1989, p. 20; Gut 2007).The difficulty may be due to the fact that, although many Cameroonian local languages and French contain consonant clusters of up to three consonants (ccc), the English clusters are generally unfamiliar to the subjects or are found at unfamiliar positions, e.g pemnboowo (barber in Fulfulde), [ntsas] (chief's residence in Ghomala), [ndzaag] (firewood in Ewondo ${ }^{4}$ ), distrait [distre] (absent-minded in French). Taylor (1995) remarks that because most languages probably have a somewhat simpler syllable structure than English, when speakers of such languages come to learn English they "face a bewildering array of unfamiliar clusters as well as familiar sounds in unfamiliar positions"' (p.6).

\section{Word Stress}

The subjects stress disyllabic and polysyllabic words in an inordinate way. Unlike their Anglophone counterparts whose word stress generally moves forward and falls on the penultimate syllable in polysyllabic words (Simo Bobda, 1986, pp.186-187), French-speaking Cameroonian users/learners of English have the tendency to stress many syllables of the word as exemplified below. 
TABLE 4

WORD STRESS IN CAMFE, CAME AND RP

$\begin{array}{lll}\text { RP form } & \text { CamFE form } & \text { CamÉ form } \\ \text { de'velop } & \text { 'dévélop } & \text { devélop } \\ \text { 'plantain } & \text { 'plan'tain } & \text { plańtain } \\ \text { es'sentially } & \text { 'es'sen'tia lly } & \text { essentially } \\ \text { Wednesday } & \text { 'Wed'nes'day } & \text { Wednséday } \\ \text { 'countryside } & \text { 'coun'try'side } & \text { countrýside } \\ \text { 'totally } & \text { 'to'ta'lly } & \text { tótally } \\ \text { dis'turbed } & \text { 'dis'turbed } & \text { diśturbed } \\ \text { 'majesty } & \text { 'majes'ty } & \text { majesty } \\ \text { 'challenge } & \text { chállenge } & \text { cha Ilenge } \\ \text { hospital } & \text { hospítal } & \text { hos'pital } \\ \text { com'pensatory } & \text { compensátory } & \text { compen'satory } \\ \text { argu'mentative } & \text { argúmeńtative } & \text { argumen'tative }\end{array}$

The table above shows that French-speaking Cameroonians pronounce English disyllabic and polysyllabic words in a jerky way. This can largely be due to the subjects' mother tongues which are syllable-timed and tone languages. In African tone languages, all vowels have a tone. Some consonants also have it at word onset to indicate their syllabic nature. French may also be one of the causes of the difficulty because of its syllable-timed nature. Although French stress has the tendency to fall on the last syllable, it is not really significant (Léon and Léon, 1987, p. 66). Yet, in some cases the subjects correctly stress some disyllabic nouns, e.g. 'pillow, 'dancing, 'singing, and verbs, e.g. co 'llect, be'have. This may have been facilitated by backward stress (BWS) and forward stress (FWS) constraints (see Simo Bobda, 2010, pp. 64-72). Like consonant clusters, English word stress is generally an area of great difficulty to many non-native speakers. Benrabah (1997) reports very interesting examples from Bansal (1969), Tiffen (1974) and Benrabah (1987) to show how misplacement of stress hinders language comprehension in non-native Englishes (p. 161). Another peculiarity which is quite particular to French-speaking Cameroonian users/learners of English is the frenchifield pronunciation of some English words. That feature constitutes the focus of the last section of this study.

\section{E. The Frenchified Pronunciation of Some English Words}

Francophone Cameroonian learners of English articulate certain English words as if they were French ones. The rule that they apply is the French reading rule, where except in very rare cases, the letters of the alphabet are pronounced in the same way in all environments. The subjects generally apply this rule when the words concerned are common to English and French, or when the English word is close to the French one. The 'frenchified pronunciation' (Remsbury, 1988, pp. 120) in question is different from spelling pronunciation in that, spelling pronunciation includes the articulation of letters which are silent in most mother tongue English. The subjects also replace certain RP vowels by typical French ones. Following are some illustrations of those features.

TABLE 5

\begin{tabular}{|c|c|c|c|}
\hline \multicolumn{4}{|c|}{ FRENCHIFIED PRONUNCIATION IN CAMFE } \\
\hline Word & RP form & CamFE & CamE \\
\hline quite & [kwart] & [kit] & [kwat] \\
\hline quality & [kwDlitI] & [kaliti] & [kwaliti] \\
\hline piece & [pi:s] & [pics] & [pis] \\
\hline rich & {$[\mathrm{rit} f]$} & [riij] & [rit5] \\
\hline maritime & [mærıtaim] & [maritim] & [maritaim/maritam] \\
\hline surely & 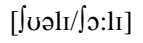 & [syrəli] & [Suoli] \\
\hline mayor & {$[\mathrm{m} \varepsilon ə]$} & [majo] & [mejo] \\
\hline efforts & [efəts] & [efo] & [efots] \\
\hline mentality & [mentəl ItI] & [mãtaliti] & [mentaliti] \\
\hline Henry & [henrI] & [ãri] & [henri] \\
\hline $\begin{array}{l}\text { fruit } \\
\text { desires }\end{array}$ & $\begin{array}{l}{[\text { fru :t] }} \\
\text { [dızaIəz] }\end{array}$ & $\begin{array}{l}\text { [fryi] } \\
\text { [dezir] }\end{array}$ & $\begin{array}{l}\text { [frut] } \\
\text { [dizajas] }\end{array}$ \\
\hline hostile & [hostail] & [ostil] & [hostail/ hostail] \\
\hline island & [arlənd] & [islan] & [ailan] \\
\hline place & [pleıs] & [plas] & [ples] \\
\hline parents & [peərənt] & [paren] & [perents] \\
\hline pressure & [pre」ə] & [prezyr] & [pre $\left.\int 0\right]$ \\
\hline during & [djuərın] & [dyrin] & [durin] \\
\hline library & [laibrərı] & [librari] & [labrari] \\
\hline pure & [pjuə] & [pyr] & [рjo] \\
\hline chair & {$\left[\mathrm{t} \int_{\varepsilon ə]}\right.$} & {$\left[\int_{\varepsilon}\right]$} & {$\left[\mathrm{t} \int \varepsilon\right]$} \\
\hline
\end{tabular}


As already pointed out, the difficulty here may largely be attributed to French, as it is the way most of the concerned words are articulated in it. The list can be extended endlessly, because 'frenchified pronunciation' is one of the major characteristics of CamFE phonology. But French interference alone cannot justify all the problems as words such as island or pressure have nothing to do with French.

\section{Discussion AND PEDAGOGiCAL IMPLiCATIONS}

The findings above show that CamFE is a quasi autonomous variety of New Englishes which distinguish itself from CamE and RP. Kouega (2008) discussed some of its consonants and vowels and Tagne Safotso (forthcoming) drew up their exhaustive list. With the multiplicity of English varieties across the world, the crucial question remains that of which variety to teach/ learn. In Cameroonian schools, RP and Standard British English are the norms, and the teaching materials are designed to promote this model. Paradoxically, very rare Cameroonian English teachers have ever gone to Britain or have ever come into contact with a native speaker. Ngefac (2011) calls this paradox the 'fallacy of promoting Standard British English accent in Cameroon', because this accent is a far-fetched phenomenon in Cameroon. In such contexts, Bamgbose (1998), Jenkins (2000, 2002) propose the teaching of EIL (English as an International Language), which would comprise the features of native and non-native Englishes. In Cameroon, applying this model with the complexity of the setting (with two local varieties) will still be a problem. The question will be "which local variety to blend with RP? CamE or CamFE, or both varieties? Maybe the solution would be ,in each subsystem of education of the country, to teach RP and its corresponding local variety, i.e. teaching RP and CamFE to French-speaking Cameroonians and RP and CamE to their fellow-citizens. The major difficulty will of course be that of the local varieties teaching materials.

\section{CONCLUSION}

This study looked at some aspects of Cameroon Francophone English (CamFE) Phonology, with focus on the plural forms/ $3^{\text {rd }}$ person singular markers '-s, -es, -os, -oes', the simple past tense/past participle morpheme '-ed', consonant clusters, word stress and the frenchified articulation of some English words. Results of the features studied (and in early studies) clearly showed that CamFE is different from CamE and RP, and constitutes a quasi autonomous variety of New Englishes. These findings also indicate that despite the promotion of RP in Cameroonian schools, the gap between this target and the local varieties widens everyday. The question that persists is thus that of the model(s) to teach/ learn in Cameroonian schools.

1. Morning Safari is a Cameroon Radio Television debate program which takes place from 5 to 6:30 a.m. from Monday to Friday.

2. Terminale is the equivalent of Upper Sixth.

3. Arabic is mostly taught in the northern regions of Cameroon where there are available teachers.

4. Fufulde, Ghomalá and Ewondo are Cameroonian home languages.

\section{APPENDIX}

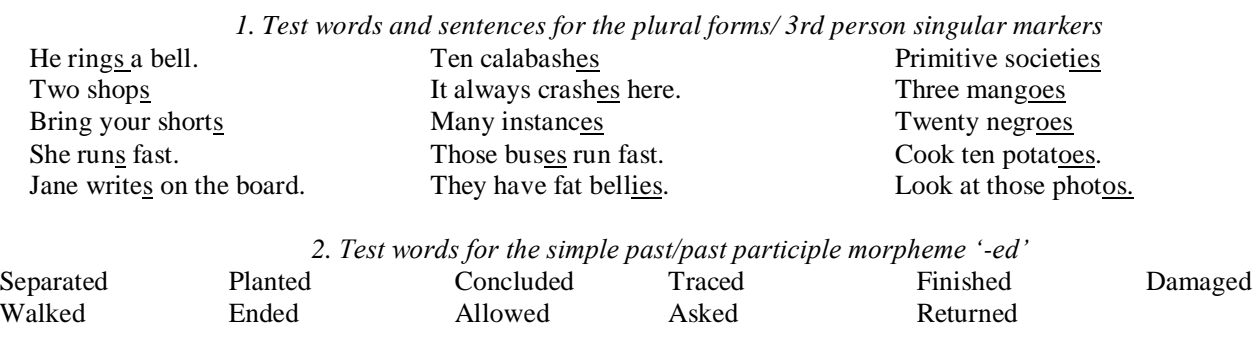

\begin{tabular}{lcccr} 
& & 3. Test words for consonant clusters & \\
Furious & Went & Think & Parents & Landlord \\
Told & Girls & Frankly & Students & Trampled \\
\hline
\end{tabular}

\begin{tabular}{|c|c|c|c|c|c|c|}
\hline \multicolumn{7}{|c|}{ 4. Test words for word stress } \\
\hline Dévelop & Éssentially & Countryside & & & 'Challenge & Compensatory \\
\hline Plantain & 'Wednesday & 'Totally & & & 'Hospital & Argúmentativ \\
\hline \multicolumn{7}{|c|}{ 5. Test words for frenchified pronunciation } \\
\hline Quite & Maritime & Mentality & Hostile & Parents & Library & Rich \\
\hline Quality & Surely & Henry & Island & Pressure & Pure & Efforts \\
\hline Piece & Mayor & Fruit & Place & During & Chair & Desires \\
\hline
\end{tabular}


[1] Bamgbose, A. (1998).Torn Between the Norms! Innovations. World Englishes, 17/1, 1-14.

[2] Bansal, R., K. (1969).The Intelligibility of Indian English. Monograph $N^{\circ} 4$.Hyderabad: Central Institute of Language.

[3] Benrabah, M. (1987). The Inintelligibility of Algerian Speakers of English: A phonetic/phonological Study. Unpublished Ph D. Thesis. London: London University College.

[4] Benrabah, M. (1997). Word-stress: A source of Inintelligibility in English. International Review of Applied Linguistics, 35/3, 157-165.

[5] Biloa, E. (1999).Bilingual Education at the University of Yaounde I: the Teaching of French to English-Speaking Students. In Echu, G. and Grundstrom A, W. (eds.), Official Bilingualism and Linguistic Communication in Cameroon. New York: Peter lang, 53-74.

[6] Bitja'a Koddy, Z.D.( 2001). Attitudes et representations linguistiques à Yaoundé. African Journal of Applied Linguistics, $\mathrm{n}^{\circ} 2$, 100-124.

[7] Djimeli, S.R.( 1997). Le français et le plurilinguisme au Cameroun. Unpublished Maîtrise Dissertation, Yaounde I University.

[8] Ebot, E.W. (1999). Phonological Peculiarities in Cameroon English. English Studies, 2, 168-179.

[9] Eboussi Boulaga,F. ed.(2009). L'Etat du Cameroun 2008, Yaounde : éditions terroir.

[10] Echu, G. (1999). Genèse et évolution du bilinguisme officiel au Cameroon.In Echu, G. and Grunsdstrom, A. W. (eds), Official Bilingualism and Linguistic communication in Cameroon. New York: Peter Lang,3-13.

[11] Gardner, R.C. and MacIntyre, P.D. (1992). A Students' contribution to second Language learning-Part I: Cognitive Variables. Language Teaching, 25/4, 211-220.

[12] Gardner, R.C and MacIntyre (1993). A Students' contribution to second language learning-Part II: Affective Variables. Language Teaching, 26/1, 1-11.

[13] Gut, U. (2007). First language influence and final consonant clusters in the new Englishes of Singapore and Nigeria. World Englishes, 26/3, 356-59.

[14] Haman Bello, M. (1997). Problématique d'une cohabitation des langues: le cas du français et du fulfulde Unpublished Maîtrise Dissertation. Ngaoundere: University of Ngaoundéré.

[15] Gbenga Fakuade. (1989). The phonological problems of Edo (Bini) Speakers of English. The British Journal of Language Teaching, Vol. 27, $\mathrm{n}^{\circ} 1,18-21$.

[16] Jenkins, J.( 2000).The Phonology of English as an International Language, Oxford: Oxford University Press.

[17] Jenkins,J.( 2002). A Sociolinguistically based, empirical researched Pronunciation syllabus for English as an International Language, Applied Linguistics 23, 83-103.

[18] Kouega, J. P. (1991). Some Speech Characteristics of Cameroon Media News in English, An Exploratory study of Radio and Television News. Unpublished $3^{\text {rd }}$ Cycle Doctorate Thesis. Yaounde: University of Yaounde.

[19] Kouega, J. P. (1999). Some Fatures of Suprasegments in Cameroon English. SOSONGO, The Cameroon Review of the Arts and Social Sciences, Vol. 1, $\mathrm{n}^{\circ} 2,57-68$.

[20] Kouega, J.P. (2000). Some Aspects of Cameroon Prosody. Alize’s, n¹9,137- 153.

[21] Kouega, J.P. (2008).The English of Francophone users in Cameroon: A phonological appraisal". Annals of the Faculty of Arts, letters and Social Sciences. Special Edition. Festchrift in honour of Professor Paul N. Mbangwana, 109-120.

[22] Léon, P. and Léon, M. (1987). Introduction à la Phonétique corrective, 2e éd. Paris: Hachette/Larousse.

[23] Mbah ,G. (2009). Langues et gestion des langues au Cameroun. In Eboussi Boulaga, F. ed. (2009), 551-569.

[24] Mbangwana, P. N. (1987). Some characteristics of sounds Patterns of Cameroon Standard English. Multilingua, 6/4, 411-424.

[25] Mbangwana, P. N. et al. ( eds.) (2006). Language, Literature Identity. Gottingen: Cuvillier Verlag.

[26] Ngefac, A.( 2011).When the Blind Lead the Blind: the Fallacy of Promoting Standard British English Accent in Cameroon, Journal of Language Teaching and Research (JLTR), 2/1, 40-44.

[27] Njika,J. (2006).Linguistic Attitudes and Socio-Cultural Integration of the Yaounde Based Anglophones in Cameroon". In Mbangwana, P. N. et al. eds. (2006), 200-209.

[28] Remsbury, J. A. (1988). Interference-Problems of Arabic-Speaking Learners of French and English, The British Journal of Language Teaching, vol.26, n², 119-125.

[29] Simo Bobda, A.( 1986). Syllable-stress in Cameroon Standard English. Annals of the Faculty of Letters and Social Sciences, vol. 2(1), 179-187.

[30] Simo Bobda, A. (1994).Aspects of Cameroon English Phonology. Bern: Peter Lang.

[31] Simo Bobda, A.(2006). The emergence of "new mother tongue" in Africa and its implications: the example of Cameroon. In Vander Walt (ed.) (2006), Living through Languages, An African Tribute to René Driven, 55-69.

[32] Simo Bobda, A.( 2010). Word stress in Cameroon and Nigerian Englishes, World Englishes, Vol.29 N ${ }^{\circ} 1,59-74$.

[33] Simo Bobda,A. And Chumbow, B. S. (1999).The Trilateral Process in Cameroon English Phonology". English World-Wide, 20/1, 35-65.

[34] Tagne Safotso, G. (2001). Impact of French and some Local Languages on English Pronunciation in Cameroon-Pedagogic Implications. A case study of Yémba and Ghomóló' Languages, Unpublished M. A. Dissertation, University of Leicester

[35] Tagne Safotso, G. (2006). The Pronunciation Problems of Ghoma'la'- French/Ewondo French Speaking learners of English and Pedagogical Implications. Unpublished Ph.D. Research Project. Yaounde: University of Yaounde I.

[36] Tagne Safotso, G. (2011). Evaluating English for Academic Purposes in some Cameroonian Universities. Journal of Education and Practice, 2/7, 62-72.

[37] Taylor, D. S. (1995). Vowels, Consonants and syllables in English: An English Teaching Perspective. International Review of Applied Linguistics, 3/1, 1-8.

[38] Tenjoh-Okwen,T.(1985). An Analysis of some Aspects of the Interlanguage of Francophone Cameroonian learners of English. Unpublished Ph. D. Thesis. Ibadan: University of Ibadan.

[39] Tiffen, W.B. (1974). The Intelligibility of Nigerian English. Unpublished Ph.D. Thesis. London: University of London.

[40] Todd, L. and Hancock, I. (1986).International English Usage. London: Croom Helm. 
[41] Wong, I. (1981). Native Speaker English for the Third World Today. In Pride, J.(ed.), New Englishes. Rowley: Newbury House Publishers,261-286.

Gilbert Tagne Safotso taught English as a Foreign Language (EFL) for over fifteen years in several high schools in Cameroon. He also taught English for Academic Purposes (EAP) for fourteen years in several faculties and departments of the University of Dschang (Cameroon). He is currently a lecturer of Applied Linguistics and English Language in the Department of English of the Higher Teacher Training College (ENS), University of Maroua, Cameroon .His research interests include English phonology, EAP and New Englishes. Gilbert Safotso has published on aspects of Cameroon culture and civilisation, and EAP. His books include Living in Turbulence, Merlin Books Ltd, and Bandjoun: Un Peuple, une Civilisation, CRAC. 